\title{
ON THE USE OF CITSCI AND VGI IN NATURAL HAZARD ASSESSMENT
}

\author{
Sultan Kocaman ${ }^{1}$, Candan Gokceoglu ${ }^{2 *}$ \\ ${ }^{1}$ Hacettepe Uni., Dept. of Geomatics Eng. 06800 Beytepe Ankara, Turkey - sultankocaman@ hacettepe.edu.tr \\ ${ }^{2}$ Hacettepe Uni., Dept. of Geological Engineering 06800 Beytepe Ankara, Turkey - cgokce@ hacettepe.edu.tr
}

\author{
Commission V, WG V/3
}

KEY WORDS: Geosciences, Citizen Science, CitSci, Volunteer Geographical Information, VGI

\begin{abstract}
:
The developments in the geospatially-enabled mobile communication technologies have opened new horizons in many fields of geosciences research, especially in those where data collection, processing and interpretation are time consuming and costly. Being one of these research fields, natural hazards also require high spatiotemporal data density and distribution, which is extremely difficult to obtain and also equally essential to secure the main assumptions of these researches and thus yield to proper conclusions. These problems can be solved with the help of citizen science (CitSci) methods and the volunteer geographical information (VGI). These two terms are complementary, or intertwined, and mutually benefit from each other for achieving their goals. This paper investigates the developments in CitSci and VGI with a specific focus of natural hazard researches and gives a brief overview of the literature. The importance of their use in natural hazards, open research areas and future aspects are also analysed. Based on the previous experiences and analyses, the authors foresee that such investigations would help researchers to utilize CitSci and VGI in their studies, and thus benefit the advantages of both approaches and improve the quality of their data. On the other hand, the growing interest of citizen scientists for supporting scientific processes could be steered to the fields where most help is needed. Specifically, detection of ground deformations after earthquakes is explained here and a simple mobile app developed for landslide data collection is briefly depicted as use case.
\end{abstract}

\section{INTRODUCTION}

CitSci is a rapidly emerging research field, which mainly explores methods and approaches for maximizing the utilization of contributions of ordinary people, volunteers and nonprofessionals into scientific processes. The Oxford English Dictionary recently defined citizen science as: "scientific work undertaken by members of the general public, often in collaboration with or under the direction of professional scientists and scientific institutions." (CSA, 2018).

According to Vetter (2011), diverse participants' status in knowledge production and consumption have been historically constructed in a variety of ways; and the amateurs were often viewed as more credible than the professionals because of independence from interest, made possible by not having to work for a living before the rise of scientific professionalization in the late nineteenth century. Indeed, amateur naturalist observations contribute to environmental and earth observation processes for over a thousand of years, such as on Japanese cherry blossoms (Primack and Higuchi, 2007) and on plants in Concord, Massachusetts, USA since 1878 (Miller-Rushing and Primack, 2008), both of which serve to understand the climate change.

The interest by amateurs and citizen scientists is again growing and there is a public demand for research projects involving CitSci (Silvertown, 2009). Such efforts are critical to achieve the aims of especially earth and ecosystem-related research projects (Silvertown, 2009) and several recent examples to environment and biodiversity monitoring can be found (Ellis and Waterton 2004, 2005; Singh et al., 2018). Regional CitSci associations (e.g. Citizen Science Association established in 2012 and also started an open access journal in 2014 (CSTP, 2018); the European Citizen Science Association (ECSA) established in 2013 (ECSA, 2013); Australian CSA established in 2014 (ACSA, 2018); Citizen Science Asia (2018)); and other local networks (CSC Zurich, 2018; ZCS, 2018) have recently been come into public scene, which make it easier for citizen scientists and researchers to meet each other and understand the requirements and needs from both sides.

The geoinformation science also benefits significantly from the geodata collected by volunteers, as can be seen from the widely used Open Street Map project (OSM, 2018). The process of map making is not only dominated by professionals anymore, and these efforts have been referred to as VGI, neogeography, geographic citizen science, crowdsourced geographic information, mashup, participatory sensing, web mapping, etc. (See et al., 2016). The most commonly used term is so far VGI, coined by Goodchild (2007) to describe user-generated content related to geographic information, is also used here to emphasize the geospatial data collection aspect of CitSci. Since VGI also involve crowdsourcing, i.e. not all the geodata collected by volunteers are intended to be used to generate scientific knowledge; it does not comply with the 10 principles of citizen science defined by ECSA (2018). Therefore, CitSci and VGI are used as intertwined but not completely overlapping terms here. They should rather be seen as complementary approaches for each other.

The main purpose of this paper is to briefly summarize the existing literature on the use of CitSci and VGI in natural hazard research, a scientific research area where CitSci and VGI

\footnotetext{
* Corresponding author
} 
can contribute significantly (Section 2); and to describe the possible use cases especially in determination and monitoring of ground deformations (Section 3). This sub-area is especially selected since the monitoring of these deformations is very difficult over large regions and with required temporal frequency. The paper is concluded by future directions of this research area.

\section{BACKGROUND OF NATURAL HAZARD RESEARCH USING CITSCI \& VGI}

Natural hazards can mainly be identified as occurrence probability of a natural phenomenon, which may have a negative effect on humans and the environment, at a given time. The geophysical (or geology- and climate-related) hazards can typically be divided into sub categories, such as landslides, floods, earthquakes, droughts, wildfires, tornados, volcanic eruptions, and avalanches (Figure 1).

In conventional natural hazard researches, following the problem definition, an investigation starts with in-situ observations and data collection by experts. However, this approach is time-consuming and slow. Due to time lags, important data can sometimes be lost and some misleading results can be concluded. To eliminate these problems, in-situ instrumentations for real time observations and data collection are possible. However, such type of instrumentation is extremely expensive. Changes in the conventional research paradigms have accelerated depending on the developments of information and communication technologies (ICT). These developments in ICT also accelerate the CitSci and VGI, which are extremely beneficial for natural hazard researches as well. The contribution levels and use cases for VGI and CitSci in natural hazards are given in Figure 1.

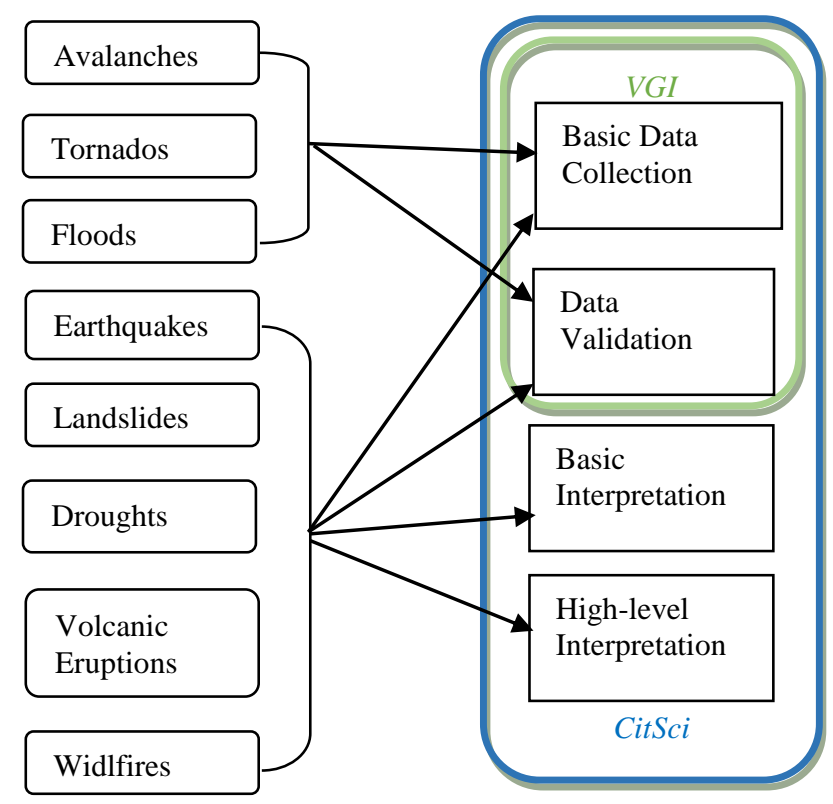

Figure 1. Natural hazard types and the use cases of CitSci and VGI in these research fields.

De Longueville et al. (2010) have proposed a workflow for the use of VGI in natural hazards with a specific example from U.K. floods. The workflow comprises of integration stages of VGI collected data from raw to validated. Schade et al. (2015) have focused on VGI sensing for crisis events and used the cases of floods in U.K. and wildfires in France for their analysis. The term VGI sensing here considers citizens as sensors and the basic data collection stage is performed as with this approach.

Nolasco-Javier and Kumar (2018) have collected data on shallow landslides for deriving the rainfall threshold in northern Philippines from newspapers, interviews of government officers, and integrated with field. Holderness and Turpin (2017) have published the results of Peta Jakarta project, which has been developed for determination of flood damages and support mitigation efforts based on social media contributions of users (i.e. VGI).

An example for ground deformation monitoring after an earthquake has been developed and presented by Liang et al. (2017), which mainly involves damages reported by volunteers, such as surface fault rupture, landslide-triggered dam or lake, rock fall, liquefaction, etc. Another study by Cochran et al. (2009) has introduced the Quake-Catcher Network (QCN), which is a seismic network that implements distributed/volunteer computing for collecting earthquake information as complementary to the traditional seismic stations. The observations of locals have been used for landslide inventory by Samodra et al. (2018) in a part of Indonesia.

\section{POSSIBLE USE OF CITSCI \& VGI IN GROUND DEFORMATION DATA COLLECTION}

Despite of the difficulties in conventional methods, researchers have tried to explain ground deformations and failures during earthquakes. The frequently encountered ground deformations and failures are landslide, rockfall, lateral spread, liquefaction and surface rupture. Depending on magnitude and focal depth, earthquakes can result in destructive effects. Ground shaking causes collapse of buildings and infrastructures but ground deformations and failures triggered by earthquakes can sometimes result in more damage and more loss of lives than ground shaking. For this reason, the deformations and failures triggered by earthquakes should be understood clearly despite of their complexities. The consequences of earthquakes in terms of ground deformations can be listed as following:

$$
\begin{array}{ll}
\text { - } & \text { Landslides (Figure 2) } \\
\text { - } & \text { Rockfalls (Figure 3) } \\
\text { - } & \text { Lateral Spreads (Figure 4) } \\
\text { - } & \text { Surface Ruption (Figure 5) } \\
\hline
\end{array}
$$

These are secondary events but they result in important losses.

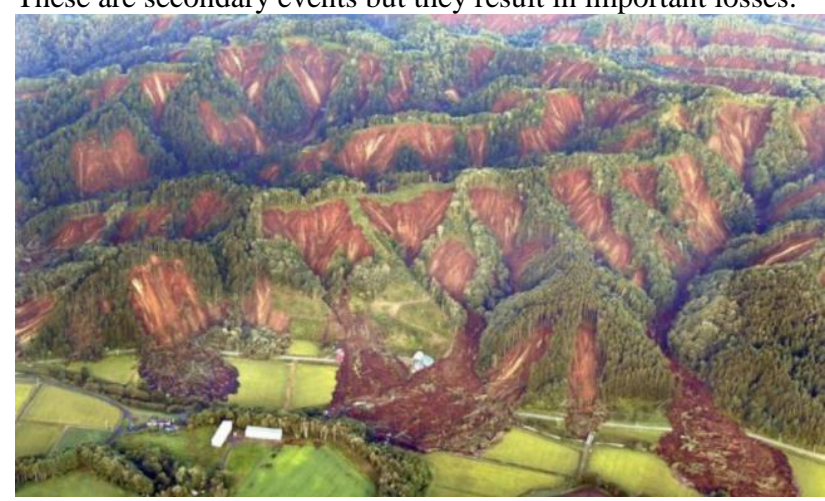

Figure 2. An example to intense landslides after the Hokkaido earthquake on September $6^{\text {th }}$, 2018. (Image credit: Tokyo Keizai) 


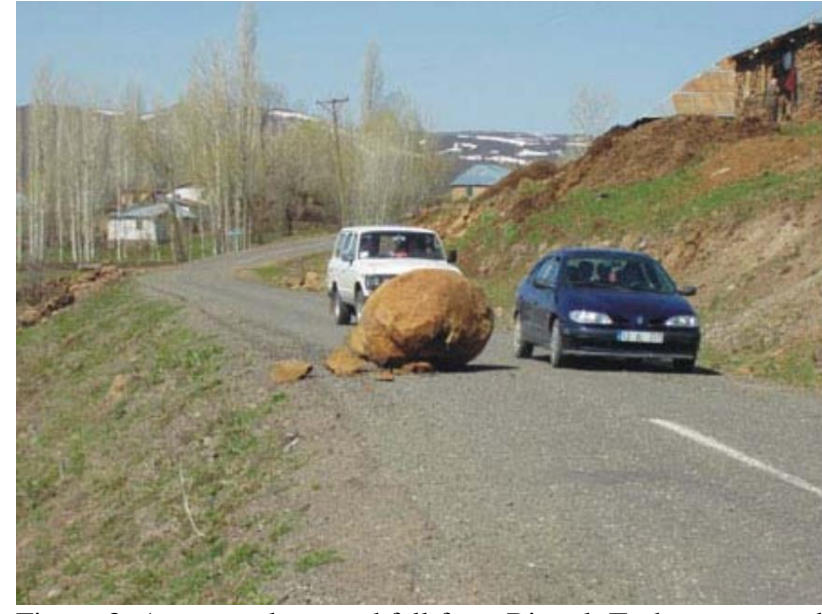

Figure 3. An example to rockfall from Bingol, Turkey, occurred after May $1^{\text {st }}, 2003$ earthquake (MTA, 2003).

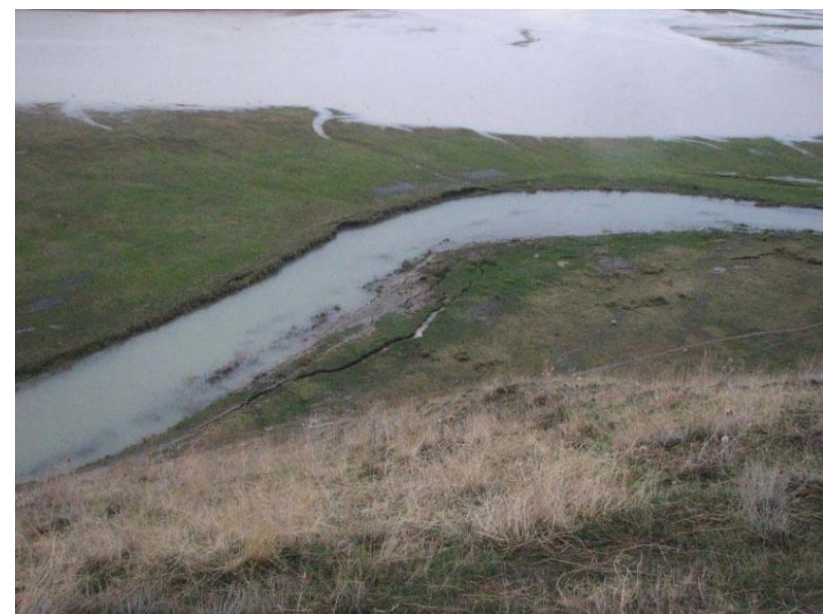

Figure 4. An example to lateral spreads from Van, Turkey, occurred after October $23^{\text {rd }}, 2011$ earthquake (MTA, 2011).

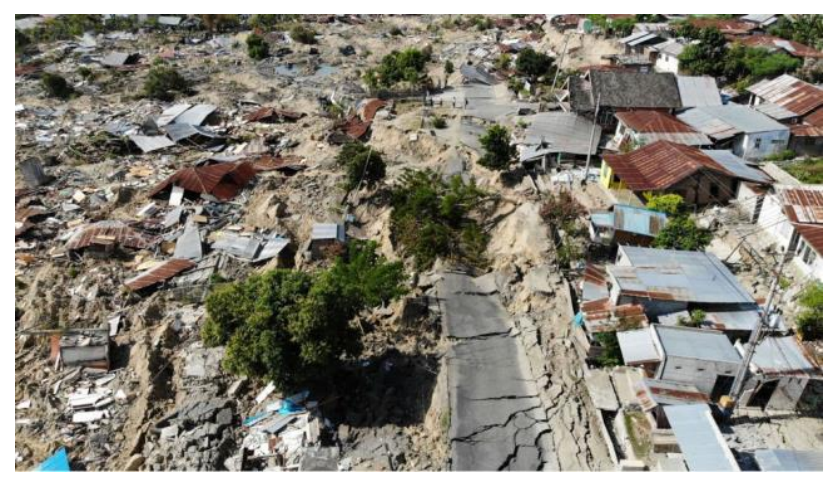

Figure 5. An example to liquefaction from Palu, Indonesia, occurred after September 28, 2018 earthquake, where shaking of the ground has caused roads to break up and houses to be swallowed (ref: news.sky.com).

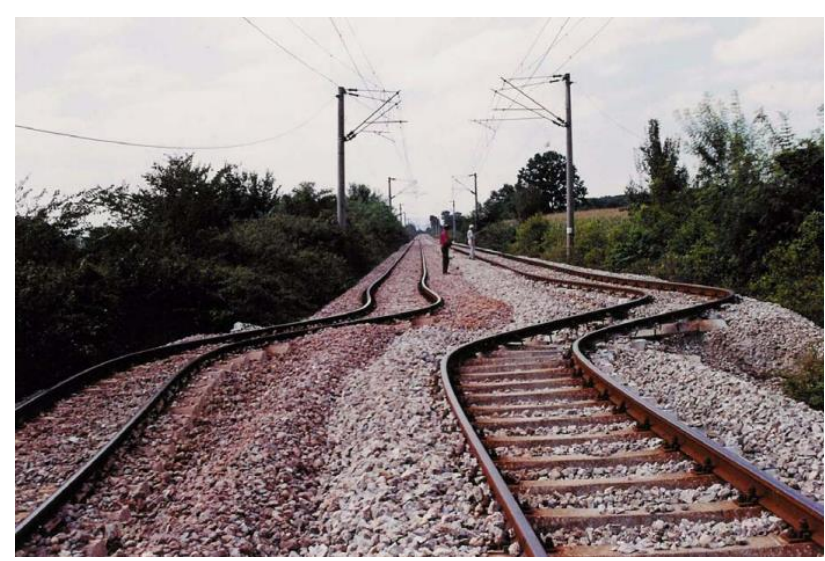

Figure 6. An example to surface rupture from Golcuk, Turkey, occurred after August 17, 1999 earthquake (Arpat, 2005).

Previous work on the use of CitSci for landslide hazard assessment by Kocaman and Gokceoglu (2018a,b) show that such structured studies in the literature and state programs are almost non-existent, and although recently large-scale projects have been initiated in U.K. (Research Councils UK, 2018) and USA (Landslide EVO, 2018; USGS Landslide Hazards Program, 2018), they are quite new and neither significant outcomes nor methods and standards are out yet.

The authors have also conceptualized and developed a mobile app for essential data collection on landslides (Kocaman and Gokceoglu, 2018c), preliminary results and analysis are planned to be presented within 2019. The data collection scheme of the app has been designed based on the previous work (e.g. Gokceoglu et al., 2005; Ocakoglu et al., 2002; Nefeslioglu et al., 2011, etc.) and experiences of the corresponding author. The main principles followed for the app design are:

i) Simplicity of the interface and the language (suitability for non-experts and several user typologies)

ii) Geo-enabled

iii) Possibility of offline data collection

iv) Photo acquisition

v) Simple description (attribution) of the event

vi) Support for cross-platform

These basic principles can be applied for any CitSci data collection tool for natural hazards. However, for higher levels of participation (i.e. validation to advanced interpretation), specific tools and algorithms should be developed. Such tools and algorithms can at best be built after collection of sufficient amount of data and initial investigations and analysis of them. 


\section{DISCUSSION AND CONCLUSION}

This study investigates the literature on the use of CitSci and VGI for natural hazards and discusses the differences between these two approaches. Both VGI and CitSci can be used as complementary methods for conventional data collection by insitu observations and instrumental monitoring. On top, both approaches can be used for data validation by using large numbers of user contributions and rule-based algorithms as well as artificial intelligence methods.

On the other hand, CitSci can contribute to natural hazard researches at higher levels, such as basic interpretation and analysis of the available data as well as higher levels by training the motivated citizen scientists. However, to be able to go up to these levels, additional efforts should be put by researchers, such as preparation of training materials and actual training.

The literature survey indicates that although the methods and applications for the use of VGI in natural hazards have been investigated to some extent, the domain is still new and there is room for more research. The same applies to CitSci even at a higher degree, since the optimal use of CitSci requires active collaboration of citizen scientists and professional scientists. Since the data collected in CitSci projects can be more structured and target oriented, they have the potential for more efficient exploitation in scientific research. It has also been shown that the number of studies comprising CitSci and natural hazards are lesser.

\section{REFERENCES}

ACSA, 2018. Australian Citizen Science Association. https://citizenscience.org.au/ (accessed on 25.09.2018).

Arpat, E., 2005. Kocaeli 1999 depreminde, ana fay kiriğinin dişinda meydana gelmiş olan deformasyonlarin nedenleri. Earthquake Symposium, March 23-25, Kocaeli, Turkey.

CSA, 2018. Citizen Science Association http://www.citizenscience.org/. (accessed on 25.09.2018).

Citizen Science Asia, 2018. http://www.citizenscience.asia/ (accessed on 25.09.2018).

Cochran, E. S., Lawrence, J. F., Christensen, C., Jakka, R., 2009. The Quake-Catcher Network: Citizen Science expanding seismic horizons. Seismol. Res. Lett. 80, 26-30.

CSC Zurich, 2018. https://citizenscience.ch/ (accessed on 25.09.2018).

CSTP, 2018. Citizen Science: Theory and Practice (CSTP). https://theoryandpractice.citizenscienceassociation.org/about/ (accessed on 25.09.2018).

De Longueville, B., Luraschi, G., Smits, P., Peedell, S., and De Groeve, T. 2010. Citizens as sensors for natural hazards: a VGI integration workflow. Geomatica 64(1):41-59.

ECSA, 2018. European Citizen Science Association. https://ecsa.citizen-science.net (accessed on 25.09.2018).

Ellis, R., and Waterton, C. 2004. Environmental Citizenship in the Making: The Participation of Volunteer Naturalists in UK
Biological Recording and Biodiversity Policy. Science and Public Policy 31:95-105.

Ellis, R., and Waterton, C. 2005. Caught between the Cartographic and the Ethnographic Imagination: The Whereabouts of Amateurs, Professionals, and Nature in Knowing Biodiversity. Environment and Planning D: Society and Space 23:673-93.

Gokceoglu, C., Sonmez, H., Nefeslioglu, H.A., Duman, T.Y., Can, T., 2005. The 17 March 2005 Kuzulu landslide (Sivas, Turkey) and landslide-susceptibility map of its near vicinity. Eng Geol 81:65-83.

Goodchild, M., 2007. Citizens as sensors: the world of volunteered geography. GeoJournal, 69, 211-21.

Holderness, T., Turpin, E., 2017. PetaJakarta.org: Assessing the Role of Social Media for Civic Co-Management During Monsoon Flooding in Jakarta, Indonesia. White Paper. SMART Infrastructure Facility, University of Wollongong ISBN: 978-174128-249-8)

Kocaman, S., Gokceoglu, C., 2018a. Possible contributions of citizen science for landslide hazard assessment. Int. Arch. Photogramm. Remote Sens. Spatial Inf. Sci., XLII-3/W4, 295300. https://doi.org/10.5194/isprs-archives-XLII-3-W4-2952018.

Kocaman, S., Gokceoglu, C., 2018b. Lessons learned from the recent landslide mitigation efforts: citizen science as a new approach. Workshop on Lessons learned from Volunteers Interactions with Geographic Citizen Science April 27, University College London, U.K.

Kocaman, S., Gokceoglu, C., 2018c. A CitSci app for landslide data collection. Landslides Journal (under review).

Kocaman, S., Anbaroglu, B., Gokceoglu, C., Altan, O., 2018. A review on citizen science (citsci) applications for disaster management. Int. Arch. Photogramm. Remote Sens. Spatial Inf. Sci., XLII-3/W4, 301-306, https://doi.org/10.5194/isprsarchives-XLII-3-W4-301-2018.

Liang, W.T., Lee, J.C., Chen, K.H., Hsiao, N.C., 2017. Citizen earthquake science in Taiwan: From science to Hazard mitigation. Journal of Disaster Research, 12(6), 1174-1181. doi: 10.20965/jdr.2017.p1174

Miller-Rushing, A. J., Primack, R. B., 2008. Global Warming and Flowering Times in Thoreau's Concord: A Community Perspective. Ecology, c. 89, Vol 2, pp. 332-341.

MTA, 2003. 1 Mayis 2003 Bingöl depremi değerlendirme raporu. Technical report, May 9. http://www.mta.gov.tr/ v3.0/sayfalar/bilgi-merkezi/deprem/pdf/01052003_bingol.pdf (accessed on 25.09.2018).

MTA, 2011. 23 Ekim 2011 Van depremi saha gözlemleri ve kaynak faya ilişkin ön değerlendirmeler. Technical report, October 30. http://www.mta.gov.tr/v3.0/sayfalar/bilgi-merkezi /deprem/pdf/2011_Van-Depremi_On-Degerlendirmeler.pdf (accessed on 25.09.2018).

NASA Landslide $\quad$ Reporter, 2018 https://pmm.nasa.gov/landslides/report.html (21.08.2018) 
Nefeslioglu, H.A., Gokceoglu, C., 2011. Probabilistic risk assessment in medium scale for rainfall induced earthflows: Catakli catchment area (Cayeli, Rize, Turkey). Mathematical Problems in Engineering, Article ID 280431, 1-21.

Nolasco-Javier, D., Kumar, L., 2018. Deriving the rainfall threshold for shallow landslide early warning during tropical cyclones: a case study in northern Philippines. Natural Hazards 90 (2): 921-941. https://doi.org/10.1007/s11069-017-3081-2

Ocakoglu, F., Gokceoglu, C., Ercanoglu, M., 2002. Dynamics of a complex mass movement triggered by heavy rainfall: a case study from NW Turkey. Geomorphology 42(3):329-341.

OSM, 2018. Open Street Map. https://www.openstreetmap.org/ (accessed on 25.09.2018).

Primack, R. B. and Higuchi, H., 2007. Cherry blossom festivals in Japan and climate change. Arnoldia 65 (2): 14-22.

Research Councils UK, 2018. http://gtr.rcuk.ac.uk/ projects?ref=NE $\% 2$ FP000452\%2F1. (accessed on 10.02.2018).

Samodra, G., Chen, G., Sartohadi, J., Kasama, K., 2018. Generating landslide inventory by participatory mapping: an example in Purwosari Area, Yogyakarta, Java. Geomorphology 306: 306-313. https://doi.org/10.1016/j.geomorph.2015.07.035

Schade, S., Díaz, L., Ostermann, F., Spinsanti, L., Luraschi, G., Cox, S., Nuñez, M., De Longueville, B., 2013. Citizen-based sensing of crisis events: sensor web enablement for volunteered geographic information. Applied Geomatics, 5(1), 3-18.

See, L.; Mooney, P.; Foody, G.; Bastin, L.; Comber, A.; Estima, J.; Fritz, S.; Kerle, N.; Jiang, B.; Laakso, M.; Liu, H.-Y.; Milčinski, G.; Nikšič, M.; Painho, M.; Pődör, A.; OlteanuRaimond, A.-M.; Rutzinger, M., 2016. Crowdsourcing, Citizen Science or Volunteered Geographic Information? The Current State of Crowdsourced Geographic Information. ISPRS Int. J. Geo-Inf., 5, 55 .

Silvertown, J., 2009. A new dawn for CitSci. Trends in Ecology \& Evolution 24, 467-471.

Singh, P., Saran, S., Kumar, D., Padalia, H., Srivastava, A., Kumar, A.S. 2018. Species Mapping Using Citizen Science Approach Through IBIN Portal: Use Case in Foothills of Himalaya. Journal of Indian Soc. Remote Sensing. https://doi.org/10.1007/s12524-018-0833-8

USGS Landslide Hazards Program, 2018. https://landslides.usgs.gov/ (accessed on 10.02.2018).

Vetter, J., 2011. Introduction: Lay Participation in the History of Scientific Observation. Science in Context, c. 24, Vol 2, pp. 127-141, June.

ZCS, 2018. https://www.zentrumfuercitizenscience.at/ (accessed on 25.09.2018). 